\title{
Lukasz Żabski
}

Uniwersytet Ekonomiczny we Wrocławiu

e-mail: lukasz.zabski@ue.wroc.pl

\section{ZASTOSOWANIE NIEPARAMETRYCZNEJ METODY DEA (DATA ENVELOPMENT ANALYSIS) DO POMIARU EFEKTYWNOŚCI SPÓŁEK KOMUNALNYCH THE APPLICATION OF NONPARAMETRIC METHOD OF DEA (DATA ENVELOPMENT ANALYSIS) TO MEASURE THE EFFICIENCY OF MUNICIPAL COMPANIES}

DOI: $10.15611 / \mathrm{pn} .2017 .481 .11$

JEL Classification: D61, H32

\begin{abstract}
Streszczenie: Głównym celem artykułu jest prezentacja wyników pomiaru efektywności spółek, w których udziały lub akcje posiadają jednostki samorządu terytorialnego, za pomocą nieparametrycznej metody DEA. W osiągnięciu powyższego celu wykorzystano metodę analizy i krytyki literatury z zakresu efektywności przedsiębiorstw, ze szczególnym uwzględnieniem sektora komunalnego, metodę badania i analizy dokumentów wewnętrznych analizowanych spółek pod kątem osiąganych wskaźników ekonomiczno-finansowych oraz nieparametryczną metodę DEA (Data Envelopment Analysis). Badaniu poddano spółki komunalne z województwa dolnośląskiego należące do trzech branż komunalnych (gospodarki mieszkaniowej, gospodarki odpadami komunalnymi oraz wodociągowo-kanalizacyjnej). Otrzymane wyniki wykazały niską efektywność działania badanych spółek komunalnych, zorientowaną na minimalizację kosztów przy dotychczas osiąganym poziomie efektów. Ponadto badanie podkreśliło utylitarne wykorzystanie metody DEA do pomiaru i oceny efektywności spółek z kapitałem publicznym.
\end{abstract}

Słowa kluczowe: nieparametryczna metoda DEA, efektywność, spółki komunalne.

Summary: The main aim of this article is to present the results of measuring the effectiveness of the companies in which units of local government own shares using the non-parametric method of DEA. In achieving the above purpose the method of analysis of literature has been used within the range of the efficiency of municipal companies, with special regard to municipal sector, method of studying the inner documents of analysed companies paying particular attention to financial-economic ratios and nonparametric Data Envelopment Analysis (DEA). The study involved municipal companies from the province of Lower Silesia belonging to three municipal sectors (housing, management of the municipal waste and waterworks-sewer). The presented results of the analysis of efficiency of the municipal companies by nonparametric DEA method are characterized by low efficiency of action 
oriented to minimizing the costs at so far level of effects. In addition, the study highlighted the utilitarian use of the DEA method to measure and evaluate the efficiency of municipal companies.

Keywords: nonparametric DEA method, efficiency, municipal companies.

\section{Wstęp}

Jednostki samorządu terytorialnego wykonują wiele zadań własnych w celu zaspokojenia potrzeb społeczności lokalnej zamieszkującej ich terytorium. W szczególności są to zadania o charakterze użyteczności publicznej, których istotą jest bieżące i nieprzerwane świadczenie i dostarczanie dóbr i usług publicznych. Tworzą one podstawę funkcjonowania gospodarki komunalnej.

Zgodnie z przepisami prawa gospodarka komunalna prowadzona przez samorząd może przybierać różne formy. Jednak najpowszechniej wybierana jest forma spółek prawa handlowego. Stanowią one obecnie ważny element sektora komunalnego, sprzyjają bowiem efektywniejszemu zarządzaniu majątkiem samorządu oraz podnoszeniu jakości świadczonych usług.

W odróżnieniu od spółek komercyjnych, głównym celem ich działania jest realizacja celów publicznych. Kwestie maksymalizacji zysku czy generowania korzyści finansowych dla właścicieli są mniej istotne, jednakże oczekuje się racjonalnego zarządzania finansami przy jednoczesnym harmonijnym zaspokajaniu potrzeb społeczeństwa.

Głównym celem artykułu jest prezentacja wyników pomiaru efektywności spółek, w których udziały lub akcje posiadają jednostki samorządu terytorialnego, za pomocą metody DEA.

W opracowaniu i interpretacji wyników posłużono się metodą statystyczną i opisową. Ponadto najważniejsze wielkości zestawiono w tabelach.

Artykuł powstał w ramach projektu sfinansowanego ze środków Narodowego Centrum Nauki przyznanych na podstawie decyzji numer DEC-2013/09/N/HS4/03695.

\section{Istota efektywności spółek komunalnych}

Efektywność jest zagadnieniem bardzo trudnym do zdefiniowania i właściwego zmierzenia [Cameron, Whetten 1983]. Jest również pojęciem interdyscyplinarnym. Stanowi obiekt zainteresowań nie tylko nauk ekonomicznych, lecz także zarządzania, socjologii, prawa, psychologii czy politologii.

W teorii ekonomii kategoria efektywności nie została jednoznacznie określona. Wielu autorów przedstawia różne definicje, których punktem wspólnym są określenia „gospodarność” czy „racjonalność”. Jednocześnie istota i pomiar efektywności budzi wiele wątpliwości, ze względu na brak uniwersalnej interpretacji tego pojęcia [Rybicki 2005, s. 370-375]. 
Efektywność można zdefiniować jako stosunek efektów ekonomicznych do nakładów; jako nakłady lub wydatki niezbędne do osiągnięcia zaplanowanych efektów lub jako okres zwrotu nakładów [Wrzosek 1994, s. 14]. Efektywność to najbardziej skuteczne zastosowanie zasobów społeczeństwa w procesie zaspokajania braków i potrzeb ludzi [Samuelson, Nordhaus 1999, s. 510].

Publikacje naukowe koncentrujące się na pomiarze efektywności usług publicznych i działalności spółek komunalnych dowodzą, że jest to zagadnienie stwarzające bardzo wiele trudności metodologicznych oraz analitycznych.

M. Kachniarz uważa, że nie istnieje właściwa metoda badania pozwalająca na rzetelne porównanie efektywności w ujęciu poszczególnych usług i na poziomie całych jednostek samorządu terytorialnego [Kachniarz 2002, s. 11]. Dodaje również, że efektywność nie jest dużym motywatorem w kształtowaniu wydatków na usługi publiczne, gdyż przede wszystkim są one oceniane pod kątem celowości i zgodności z przepisami prawa. Ponadto sugeruje, że poziom efektywności usług publicznych wynika z czynników wewnętrznych kształtowanych pod wpływem decyzji lokalnych władz samorządowych.

P. Malinowski wyraża pogląd, że spółki prawa handlowego jako forma prowadzenia gospodarki komunalnej powinny odznaczać się określoną efektywnością i racjonalnością działania [Malinowski 2013, s. 92]. Ponadto w literaturze podkreśla się, że podmioty z kapitałem prywatnym są efektywniejsze niż podmioty z kapitałem publicznym. Dla potwierdzenia tej tezy podaje się badania E.S. Savasa, który stwierdził, że sektor prywatny jest o połowę tańszy od publicznego przy realizacji tych samych usług użyteczności publicznej [Savas 1992, s. 31].

Z. Gruszewski stwierdza natomiast, że w sektorze publicznym często występuje problem niskiej efektywności oraz potrzeba budowania przewagi konkurencyjnej w gospodarowaniu zasobami, ponieważ bodźce do monitorowania nie są wystarczająco silne, gdyż organizacje takie bardziej są skupione na realizacji zadań publicznych, a nie na generowaniu zysku [Gruszewski 2002, s. 273].

Podsumowując, należy stwierdzić, że efektywność stanowi ważne zagadnienie nie tylko na gruncie sektora prywatnego, ale także na gruncie sektora komunalnego. Właściwe zarządzanie majątkiem publicznym ukierunkowane na osiąganie celów publicznych powinno stanowić fundament podnoszenia efektywności działalności spółek prawa handlowego z kapitałem jednostek samorządu terytorialnego.

\subsection{Pomiar efektywności spółek komunalnych}

W celu określenia efektywności działalności spółek komunalnych wykorzystuje się najczęściej analizę ekonomiczną. Stanowi ona system badania i oceny efektywności działania przedsiębiorstwa. Klasycznie wyróżnia się dwie jej kategorie: analizę techniczno-ekonomiczną oraz analizę finansową. Pierwsza analiza dotyczy oceny rzeczowych i osobowych aspektów funkcjonowania podmiotu gospodarczego. Druga analiza koncentruje się na ocenie finansowych aspektów przedsiębiorstwa [Leszczyński, Skowronek-Mielczarek 2004, s. 178]. 
Na podstawie studiów literaturowych można wskazać, że właściwe dla pomiaru efektywności spółek komunalnych mogą być mierniki:

- określające wielkość zrealizowanych usług (mierniki skuteczności);

- określające zjawiska ekonomiczno-finansowe.

Do pierwszej grupy można zaliczyć mierniki skuteczności dla poszczególnych branż komunalnych. Dla branży wodociągowo-kanalizacyjnej miernikiem skuteczności może być wskaźnik gęstości sieci wodociągowej i kanalizacyjnej w km do powierzchni jednostki osadniczej w $\mathrm{km}^{2}$. Dla branży ciepłowniczej - wskaźnik dostępności usług ciepłowniczych (relacja długości sieci ciepłowniczej do liczby mieszkańców danej jednostki osadniczej). Dla branży komunikacji miejskiej - liczba wozokilometrów (iloczyn liczby wozów w eksploatacji, średniego dobowego czasu kursowania jednego wozu w godzinach i prędkości eksploatacyjnej w km/h. Z kolei miernikiem skuteczności spółki świadczącej usługi z branży gospodarowania odpadami może być np. wskaźnik ilości odpadów stałych na 1 mieszkańca [Grzymała 2010, s. 53-56].

Do drugiej grupy mierników można zaliczyć wskaźniki rentowności, płynności finansowej, zadłużenia i sprawności gospodarowania.

W. Bachor proponuje, aby efektywność spółek komunalnych badać w oparciu o efektywność wykorzystania środków trwałych [Bachor 2009, s. 143] oraz dokonując analizy poziomu i struktury poniesionych w nich kosztów. Koszty są pieniężnym wyrazem wykorzystania określonych zasobów produkcyjnych, a przychody zależą od praktyki taryfowej władz samorządu lub innego regulatora. Tym samym, określając efektywność gospodarowania majątkiem trwałym, należy posłużyć się kosztami z działalności operacyjnej i przychodami ze sprzedaży.

Efektywność spółek komunalnych można także mierzyć stopniem zaspokajania potrzeb społeczeństwa. Jednak wydaje się ono zagadnieniem bardzo trudnym i niekiedy mało mierzalnym. E. Wojciechowski jest zdania, że działalność samorządu oceniana jest przez pryzmat świadczonych usług i ich jakości, co wskazuje, że opinia o samorządzie opiera się na relacjach z administracją samorządową [Wojciechowski 2003, s. 107].

Warto również uzupełnić, że oprócz metod pomiaru efektywności opartych na podejściu wskaźnikowym stosuje się także metody parametryczne i nieparametryczne. W metodach parametrycznych bazuje się na funkcji produkcji określającej zależność techniczną pomiędzy nakładami a produkcją i przedstawiającej maksymalną ilość produktu, jaka może być otrzymana przy określonym poziomie nakładów. Parametry funkcji produkcji szacowane są na podstawie instrumentów właściwych dla estymacji ekonometrycznej. Wyróżnia się wobec tego metodę SFA (Stochastic Frontier Approach), TFA (Thick Frontier Approach) oraz DFA (Distribution Free Approach) [Borkowski, Dudek, Szczęsny 2003, s. 158].

W nieparametrycznych metodach pomiaru efektywności bazuje się na programowaniu liniowym bez uwzględnienia wpływu czynnika losowego i potencjalnych błędów pomiaru. W metodach tych nie dokonuje się analizy zależności pomiędzy nakładami i wynikami. Do najpopularniejszych metod zalicza się DEA (Data Envelopment Analysis) oraz FDH (Free Disposal Hull) [Szymańska 2010, s. 159]. 


\section{Założenia metody DEA (Data Envelopment Analysis)}

Stosując założenia efektywności opartej na wskaźnikach finansowych, nie można jednak określić stopnia adekwatności poniesionych nakładów do uzyskanych efektów [Gajdzik 2015, s. 424-428]. Mają one głównie charakter jednowymiarowy. Tym samym, chcąc pozyskać informację, czy można osiągnąć wyższą efektywność przy już poniesionych nakładach, proponuje się wykorzystanie efektywności technicznej rozumianej jako maksymalny stopień minimalizowania nakładów przy określonym poziomie efektów.

Powyższe podejście do pomiaru efektywności umożliwia nieparametryczna metoda DEA (Data Envelopment Analysis). Generuje ona wiele podejść, które uwzględniają różne aspekty działalności podmiotów gospodarczych. Umożliwiają one następnie obliczenie porównywalnych wskaźników odzwierciedlających wielość nakładów i efektów.

W metodzie DEA nie występuje składnik losowy oraz nie jest wymagane dokładne określenie zależności funkcji pomiędzy nakładami a efektami. Autorami tej metody są A. Charnes, W.W. Cooper oraz E. Rhodes.

Do estymacji miar efektywności technicznej wykorzystali oni programowanie matematyczne. Efektem analiz było powstanie modelu CCR - od pierwszych liter nazwisk autorów tej metody [Pawłowska 2005, s. 22]. Ponadto bazując na koncepcji produktywności rozumianej jako stosunek pojedynczego wyniku i pojedynczego nakładu, przeprowadzili wielowymiarową analizę, w której można dysponować więcej niż jednym nakładem i więcej niż jednym efektem [Rogowski, Pawłowska, Kopczewski 2003, s. 50].

W ten sposób został przedstawiony praktyczny model pomiaru efektywności zdefiniowany jako:

$$
\text { EFEKTYWNOŚĆ }=\frac{\sum_{r=1}^{s} \mu_{r} \text { EFEKT }_{r}}{\sum_{i=1}^{m} v_{i} N A K Ł A D_{i}}
$$

gdzie: $s$ - liczba efektów,

$m$ - liczba nakładów,

$\mu_{r}$ - wagi określające ważność poszczególnych efektów,

$v_{i}$ - wagi określające ważność poszczególnych nakładów.

Efektywny jest ten podmiot, który albo maksymalizuje osiągane efekty przy danym poziomie nakładów, albo minimalizuje nakłady w celu osiągnięcia określonego poziomu efektów [Jurek 2005, s. 121-122].

$\mathrm{W}$ metodzie tej wagi nie muszą być znane. Są one ustalane w trakcie analizy efektywności. Wagi dobierane są dla każdego obiektu tak, aby maksymalizować jego efektywność. 
Metoda DEA umożliwia określenie krzywej efektywności (best practice frontier) na podstawie zdefiniowanych nakładów i efektów. W metodzie DEA zakłada się, że nakłady i efekty są nieujemne i wyrażone w jednolitych jednostkach dla każdej jednostki z badanego zbioru (DMU - Data Making Unit). Ponadto efekty muszą być tak sformułowane, by ich wzrost był oceniany pozytywnie, a nakłady negatywnie. $\mathrm{Na}$ krzywej efektywności znajdują się wszystkie najbardziej efektywne jednostki. Oznacza to, że efektywną jednostką będzie ta, która znajduje się na krzywej efektywności i jej efektywność wynosi 1\%. Efektywność obiektu jest zatem mierzona wzglądem innych obiektów z badanej grupy [Guzik 2009, s. 30]. W przypadku jednostek decyzyjnych (DMU) znajdujących się poniżej krzywej poziom nieefektywności obliczany jest jako odległość dzieląca je od granicy możliwości produkcyjnych.

W praktyce występuje bardzo wiele modeli DEA klasyfikowanych na podstawie orientacji modelu oraz rodzaju efektów działalności ${ }^{1}$.

Najogólniej modele DEA budowane na podstawie orientacji dotyczą:

1. orientacji na koszt działalności, w którym dokonuje się minimalizacji nakładów przy ograniczeniu na dolną wielkość efektów;

2. orientacji na wynik działalności, w którym dokonuje się maksymalizacji efektów przy ograniczeniu na górną wielkość nakładów.

$\mathrm{Z}$ kolei modele DEA oparte na rodzaju efektów skali to modele $\mathrm{BCC}^{2}$ (zmienne efekty skali) oraz $\mathrm{CCR}^{3}$ (stałe efekty skali).

Metoda DEA jest szczególnie użyteczna w przypadku oceny efektywności podmiotów gospodarczych, które działają na rynkach zniekształconych w wyniku stosowania zewnętrznych taryf, cen i braku konkurencyjności. Podstawowe rynkowe wskaźniki nie mogą dać pełnej, precyzyjnej oceny działalności przedsiębiorstwa, gdyż nie uwzględniają wielu jej wymiarów [Ćwiąkała-Małys, Nowak 2009]. W związku z powyższym metoda DEA była skutecznie stosowana do oceny przedsiębiorstw handlowych, non profit czy fundacji.

Należy dodać, że metoda DEA w pomiarze efektywności posiada pewne ograniczenia. Dotyczą one przede wszystkim dużej wrażliwości na błędne dane oraz na dane znacznie różniące się od pozostałych, a także dużą wrażliwość na zmianę liczby jednostek (DMU) [Kozłowska 2014, s. 308-309]. Dodatkowo zachodzi konieczność zachowania proporcji pomiędzy liczbą zmiennych modelu, tj. nakładów i efektów, a liczbą badanych jednostek decyzyjnych (DMU). Istotnym ograniczeniem jest również to, że metoda pozwala badać tylko podmioty do siebie podobne. W przeciwnym wypadku można otrzymać wyniki nieprezentujące w sposób rzetelny obrazu efektywności badanych podmiotów.

\footnotetext{
${ }^{1} \mathrm{~W}$ literaturze można również spotkać określenie metody granicznej analizy danych.

${ }^{2}$ Nazwa pochodzi od nazwisk autorów modelu (Banker, Charnes, Cooper).

${ }^{3}$ Nazwa pochodzi od nazwisk autorów modelu (Charnes, Cooper, Rhodes).
} 


\section{Pomiar efektywności wybranych spólek komunalnych metodą DEA - wyniki analizy}

Efektywność spółek komunalnych stanowiła jeden z obiektów zainteresowań autora W zrealizowanym projekcie badawczym dotyczącym efektywności nadzoru właścicielskiego nad spółkami komunalnymi w województwie dolnośląskim. W realizacji projektu przyjęto, że efektywność nadzoru właścicielskiego znajduje swój wyraz w efektywności przedsiębiorstwa. Efektywność taka jest mierzona na podstawie wyników finansowych spółek.

Przedmiotem analizy były wskaźniki ekonomiczno-finansowe wybranych spółek komunalnych, w których większościowe udziały lub akcje są w posiadaniu gmin z województwa dolnośląskiego. Do porównania wybrano spółki z branży wodociągowo-kanalizacyjnej $(n=41)$, gospodarki mieszkaniowej $(n=30)$ oraz gospodarki odpadami komunalnymi $(n=18)$. Wybór branż podyktowany był występowaniem dużej liczby podmiotów komunalnych świadczących konkretne usługi na terenie analizowanego województwa.

W celu określenia efektywności wybranych spółek komunalnych zastosowano nieparametryczną metodę DEA. Umożliwia ona uwzględnienie różnych aspektów działalności podmiotów gospodarczych, a także obliczenie porównywalnych wskaźników odzwierciedlających wielkość nakładów i efektów.

W analizie efektowności badanych spółek komunalnych wykorzystano model BCC (zmienne efekty skali) zorientowany na nakłady, ponieważ zdaniem autora $\mathrm{w}$ interesie tych podmiotów jest wykonywanie określonych zadań publicznych przy jak najmniejszym nakładzie, czyli ponoszonych kosztów. Dodatkowo efekty działalności zależą od rynku, a więc w dużym stopniu są niezależne od spółek. Ponadto jako uzasadnienie wykorzystania modelu BCC zakładającego zmienne efekty skali można podać to, że w praktyce gospodarczej spółki osiągają korzyści lub niekorzyści skali odpowiednio, gdy koszty działalności rosną lub spadają. Model CCR nie jest odpowiedni do opisu zmiennych efektów skali.

Zmienne do konstrukcji modeli określono w następujący sposób:

- efekty:

1. rentowność aktywów (ROA),

2. rentowność kapitału własnego (ROE),

3. produktywność majątku trwałego;

- nakłady:

1. koszty działalności operacyjnej,

2. aktywa trwałe,

3. kapitał zakładowy.

Warto w tym miejscu zaznaczyć, że dobór do modelu kosztów działalności operacyjnej jako nakłady wynikał z tego, że spółki komunalne z natury prowadzonej działalności są kosztochłonne i zgodnie z przyjętym modelem zorientowanym na nakłady dążono do ich obniżenia, zwiększając tym samym efekty.

Obliczenie wskaźników efektywność metodą DEA przebiegało w następujący sposób: 
1. dokonano wyboru nakładów i efektów, które we właściwy sposób będą obrazować efektywność spółki. Na podstawie studiów literaturowych uwagę skoncentrowano na wskaźnikach mierzących produktywność majątku trwałego oraz efektywność zarządzania kapitałem własnym zaangażowanym przez gminy. Kształtowanie się wybranych wskaźników przeanalizowano dla okresu 2010-2013;

2. badane spółki komunalne z województwa dolnośląskiego $(n=89)$ podzielono wg branż, w których funkcjonują. W szczególności kryterium pogrupowania był główny przedmiot działalności spółki wpisany w Krajowym Rejestrze Sądowym. Była to fundamentalna czynność, ponieważ poszczególnie mierniki mogą przybierać różne wartości z powodu specyfiki branży, w której funkcjonuje spółka, a także ze względu na charakter świadczonych usług. Nieodpowiednie, zdaniem autora, byłoby porównywanie sytuacji ekonomiczno-finansowej spółek wodociągowo-kanalizacyjnych ze spółkami gospodarującymi zasobem mieszkaniowym. W obu przypadkach wiele czynników zewnętrznych i wewnętrznych determinuje poziom poniesionych kosztów oraz uzyskiwanych efektów;

3. zgodnie z wymogiem metody DEA dotyczącym wartości danych nieujemnych dokonano w przypadku wartości ujemnych w nakładach i efektach przesunięcia przez dodanie stałej wartości liczbowej do danych, tak by były nieujemne, tj. wynosiły nie mniej niż 0 .

Do obliczeń wykorzystano program DEAP 2.1.

Otrzymane wskaźniki efektywności dostarczają informacji, o ile proporcjonalnie mniej jednostka efektywna powinna zredukować nakłady, aby osiągnąć efekt na tym samym poziomie. Spółki efektywne pod względem nakładów to te, które nie będą mogły proporcjonalnie zmniejszyć wysokości nakładów w celu uzyskania tych samych efektów. Z kolei nieefektywne spółki mogą zwiększyć swoją efektywność w wyniku obniżenia ponoszonych nakładów.

Tabela 1. Średnie wskaźniki efektywności DEA badanych spółek w podziale na branże w latach 2010-2013

\begin{tabular}{|l|c|c|c|c|}
\hline \multicolumn{1}{|c|}{ Branża } & 2010 & 2011 & 2012 & 2013 \\
\hline Gospodarki mieszkaniowej & 0,421 & 0,370 & 0,490 & 0,407 \\
\hline $\begin{array}{l}\text { Gospodarki odpadami } \\
\text { komunalnymi }\end{array}$ & 0,251 & 0,286 & 0,289 & 0,297 \\
\hline Wodociągów i kanalizacji & 0,233 & 0,258 & 0,232 & 0,243 \\
\hline
\end{tabular}

Źródło: opracowanie własne na podstawie przeprowadzonych badań.

Z liczb przedstawionych w tabeli 1 wynika, że najwyższe, średnie wskaźniki efektywności w badanym okresie odnotowano w przypadku spółek należących do branży gospodarki mieszkaniowej. Z kolei najniższe średnie wskaźniki odnotowywały spółki z branży gospodarki odpadami oraz wodociągów i kanalizacji. Średnio o 70\% powinny one zmniejszyć nakłady, aby osiągnąć dotychczasowy poziom wyników. 
Dla pełniejszego zobrazowania kształtowania się wskaźników efektywności w latach 2010-2013 przedstawiono wyniki wszystkich analizowanych spółek komunalnych z województwa dolnośląskiego należących do wyodrębnionych branż gospodarki komunalnej.

Tabela 2. Wskaźniki efektywności DEA spółek komunalnych z branży gospodarki mieszkaniowej w latach 2010-2013

\begin{tabular}{|c|c|c|c|c|c|c|}
\hline Miejscowość & Nazwa spółki & 2010 & 2011 & 2012 & 2013 & Średnia \\
\hline 1 & 2 & 3 & 4 & 5 & 6 & 7 \\
\hline $\begin{array}{l}\text { Gmina Miejska } \\
\text { Bielawa }\end{array}$ & $\begin{array}{l}\text { Towarzystwo Budownictwa } \\
\text { Społecznego Bielawa } \\
\text { Sp. z o.o. }\end{array}$ & 0,383 & 0,356 & 0,456 & 0,237 & 0,358 \\
\hline $\begin{array}{l}\text { Gmina Miejska } \\
\text { Bielawa }\end{array}$ & $\begin{array}{l}\text { Miejski Zarząd Budynków } \\
\text { Mieszkalnych Sp. z o.o. }\end{array}$ & 0,197 & 0,172 & 0,350 & 0,214 & 0,233 \\
\hline $\begin{array}{l}\text { Gmina Miejska } \\
\text { Boguszów- } \\
\text {-Gorce }\end{array}$ & $\begin{array}{l}\text { Zakład Gospodarki Mieszkaniowej } \\
\text { Sp. z o.o. }\end{array}$ & 1,000 & 0,476 & 1,000 & 1,000 & 0,869 \\
\hline $\begin{array}{l}\text { Gmina Miejska } \\
\text { Bolesławiec }\end{array}$ & $\begin{array}{l}\text { Towarzystwo Budownictwa } \\
\text { Społecznego W Bolesławcu Sp. z o.o. }\end{array}$ & 0,149 & 0,091 & 0,093 & 0,109 & 0,111 \\
\hline $\begin{array}{l}\text { Gmina Miejska } \\
\text { Dzierżoniów }\end{array}$ & $\begin{array}{l}\text { Dzierżoniowskie Towarzystwo } \\
\text { Budownictwa Społecznego Sp. z o.o. }\end{array}$ & 0,314 & 0,203 & 0,176 & 0,226 & 0,230 \\
\hline $\begin{array}{l}\text { Gmina Miejska } \\
\text { Dzierżoniów }\end{array}$ & $\begin{array}{l}\text { Dzierżoniowski Zarząd Budynków } \\
\text { Mieszkalnych Sp. z o.o. }\end{array}$ & 0,686 & 0,366 & 0,955 & 0,380 & 0,597 \\
\hline $\begin{array}{l}\text { Gmina } \\
\text { Miejska Głogów }\end{array}$ & $\begin{array}{l}\text { Towarzystwo Budownictwa } \\
\text { Społecznego Sp. z o.o. }\end{array}$ & 0,079 & 0,059 & 0,042 & 0,051 & 0,058 \\
\hline $\begin{array}{l}\text { Gmina } \\
\text { Miejska Jawor }\end{array}$ & Ciepło Jawor Sp. z o.o. & 0,875 & 0,717 & 1,000 & 0,561 & 0,788 \\
\hline $\begin{array}{l}\text { Gmina Miejska } \\
\text { Jelenia Góra }\end{array}$ & $\begin{array}{l}\text { Jeleniogórskie Towarzystwo } \\
\text { Budownictwa Społecznego Sp. z o.o. }\end{array}$ & 0,188 & 0,194 & 0,150 & 0,281 & 0,203 \\
\hline $\begin{array}{l}\text { Gmina Miejska } \\
\text { Kamienna Góra }\end{array}$ & Spółka Mieszkaniowa Sp. z o.o. & 0,395 & 0,287 & 0,662 & 0,302 & 0,412 \\
\hline $\begin{array}{l}\text { Gmina Miejska } \\
\text { Kłodzko }\end{array}$ & $\begin{array}{l}\text { Zakład Administracji Mieszkaniami } \\
\text { Gminnymi Gminy Miejskiej Kłodzko } \\
\text { Sp. z o.o. w Kłodzku }\end{array}$ & 0,319 & 0,059 & 0,118 & 0,047 & 0,136 \\
\hline $\begin{array}{l}\text { Gmina } \\
\text { Miejska Legnica }\end{array}$ & $\begin{array}{l}\text { Strefa Aktywności Gospodarczej } \\
\text { Sp. z o.o. }\end{array}$ & 0,168 & 0,208 & 0,234 & 0,154 & 0,191 \\
\hline $\begin{array}{l}\text { Gmina } \\
\text { Miejska Lubań }\end{array}$ & $\begin{array}{l}\text { Lubańskie Towarzystwo Budownictwa } \\
\text { Społecznego Sp. z o.o. }\end{array}$ & 1,000 & 0,496 & 0,496 & 0,568 & 0,640 \\
\hline $\begin{array}{l}\text { Gmina } \\
\text { Miejska Lubin }\end{array}$ & $\begin{array}{l}\text { Regionalne Towarzystwo } \\
\text { Budownictwa Społecznego Sp. z o.o. }\end{array}$ & 0,066 & 0,090 & 0,117 & 0,063 & 0,084 \\
\hline $\begin{array}{l}\text { Gmina Miejska } \\
\text { Nowa Ruda }\end{array}$ & $\begin{array}{l}\text { Noworudzkie Towarzystwo } \\
\text { Budownictwa Społecznego Sp. z o.o. }\end{array}$ & 1,000 & 1,000 & 1,000 & 1,000 & 1,000 \\
\hline
\end{tabular}




\begin{tabular}{|c|c|c|c|c|c|c|}
\hline 1 & 2 & 3 & 4 & 5 & 6 & 7 \\
\hline $\begin{array}{l}\text { Gmina Miejska } \\
\text { Piechowice }\end{array}$ & $\begin{array}{l}\text { Zarząd Nieruchomości Wspólny Dom } \\
\text { Sp. z o.o. }\end{array}$ & 0,605 & 0,555 & 0,727 & 0,544 & 0,608 \\
\hline $\begin{array}{l}\text { Gmina Miejska } \\
\text { Piława Górna }\end{array}$ & $\begin{array}{l}\text { Zarząd Budynków Mieszkalnych } \\
\text { Sp. z o.o. }\end{array}$ & 0,350 & 0,419 & 0,779 & 0,776 & 0,581 \\
\hline $\begin{array}{l}\text { Gmina Miejska } \\
\text { Świdnica }\end{array}$ & $\begin{array}{l}\text { Świdnickie Towarzystwo } \\
\text { Budownictwa Społecznego Sp. z o.o. }\end{array}$ & 0,276 & 0,197 & 0,239 & 0,150 & 0,216 \\
\hline $\begin{array}{l}\text { Gmina Miejska } \\
\text { Wałbrzych }\end{array}$ & Miejski Zarząd Budynków Sp. z o.o. & 0,014 & 0,025 & 1,000 & 0,088 & 0,282 \\
\hline $\begin{array}{l}\text { Gmina Miejska } \\
\text { Wrocław }\end{array}$ & Wrocławskie Mieszkania Sp. z o.o. & 0,067 & 0,062 & 0,040 & 0,032 & 0,050 \\
\hline $\begin{array}{l}\text { Gmina Miejska } \\
\text { Zgorzelec }\end{array}$ & $\begin{array}{l}\text { Przedsiębiorstwo Zarządu } \\
\text { Nieruchomościami Sp. z o.o. }\end{array}$ & 0,297 & 0,208 & 0,196 & 0,214 & 0,229 \\
\hline $\begin{array}{l}\text { Gmina Miejska } \\
\text { Zgorzelec }\end{array}$ & $\begin{array}{l}\text { Zgorzeleckie Towarzystwo } \\
\text { Budownictwa Społecznego Sp. z o.o. }\end{array}$ & 0,158 & 0,206 & 0,228 & 0,319 & 0,228 \\
\hline $\begin{array}{l}\text { Gmina Miejsko- } \\
\text {-Wiejska } \\
\text { Bogatynia }\end{array}$ & $\begin{array}{l}\text { Gminny Zarząd Mienia Komunalnego } \\
\text { w Bogatyni Sp. z o.o. }\end{array}$ & 0,252 & 0,274 & 1,000 & 1,000 & 0,632 \\
\hline $\begin{array}{l}\text { Gmina Miejsko- } \\
\text {-Wiejska } \\
\text { Bogatynia }\end{array}$ & $\begin{array}{l}\text { Towarzystwo Budownictwa } \\
\text { Społecznego Sp. z o.o. }\end{array}$ & 0,170 & 0,160 & 0,165 & 0,238 & 0,183 \\
\hline $\begin{array}{l}\text { Gmina Miejsko- } \\
\text {-Wiejska } \\
\text { Głuszyca }\end{array}$ & $\begin{array}{l}\text { Zakład Usług Mieszkaniowych } \\
\text { i Komunalnych Sp. z o.o. }\end{array}$ & 0,655 & 0,793 & 0,287 & 0,570 & 0,576 \\
\hline $\begin{array}{l}\text { Gmina Miejsko- } \\
\text {-Wiejska Jelcz- } \\
\text {-Laskowice }\end{array}$ & $\begin{array}{l}\text { Zakład Gospodarki Mieszkaniowej } \\
\text { Towarzystwo Budownictwa } \\
\text { Społecznego Sp. z o.o. z siedzibą w } \\
\text { Jelczu- Laskowicach }\end{array}$ & 0,290 & 0,172 & 0,270 & 0,176 & 0,227 \\
\hline $\begin{array}{l}\text { Gmina Miejsko- } \\
\text {-Wiejska } \\
\text { Niemcza }\end{array}$ & $\begin{array}{l}\text { Przedsiębiorstwo Komunalne } \\
\text { Sp. z o.o. }\end{array}$ & 1,000 & 1,000 & 1,000 & 1,000 & 1,000 \\
\hline $\begin{array}{l}\text { Gmina Miejsko- } \\
\text {-Wiejska } \\
\text { Polkowice }\end{array}$ & $\begin{array}{l}\text { Polkowickie Towarzystwo } \\
\text { Budownictwa Społecznego Sp. z o.o. }\end{array}$ & 0,071 & 0,052 & 0,056 & 0,529 & 0,177 \\
\hline $\begin{array}{l}\text { Gmina Miejsko- } \\
\text {-Wiejska Syców }\end{array}$ & \begin{tabular}{|l} 
Sycowskie Towarzystwo \\
Budownictwa Społecznego Sp. z o.o.
\end{tabular} & 0,471 & 1,000 & 1,000 & 0,328 & 0,700 \\
\hline $\begin{array}{l}\text { Gmina Miejsko- } \\
\text {-Wiejska } \\
\text { Ząbkowice } \\
\text { Śląskie }\end{array}$ & $\begin{array}{l}\text { Towarzystwo Budownictwa } \\
\text { Społecznego Ząbkowice Śląskie } \\
\text { Sp. z o.o. }\end{array}$ & 0,564 & 0,576 & 0,368 & 0,466 & 0,494 \\
\hline $\begin{array}{l}\text { Gmina Wiejska } \\
\text { Walim }\end{array}$ & $\begin{array}{l}\text { Administracja Budynków } \\
\text { Komunalnych Sp. z o.o. }\end{array}$ & 1,000 & 1,000 & 1,000 & 1,000 & 1,000 \\
\hline
\end{tabular}

Źródło: opracowanie własne na podstawie przeprowadzonych badań. 
Spośród wszystkich badanych spółek komunalnych z branży gospodarki mieszkaniowej tylko trzy w badanym okresie były efektywne (tab. 2). Pozostałe $96 \%$ nie gospodarowało racjonalne swoimi zasobami. Ponosiły one znaczące nakłady w celu osiągnięcia takiego samego poziomu efektów. Tylko około 30\% spółek komunalnych zajmujących się działalnością z zakresu gospodarki mieszkaniowej osiągało wskaźnik efektywności ponad 50\%. Oznacza to, że podmioty te powinny średnio o 50\% zmniejszyć nakłady w celu osiągnięcia dotychczasowych efektów.

Warto w tym miejscu dodać również, że spółki gospodarujące substancją mieszkaniową na terenie gminy zmagają się nie tylko z problemem wysokiej amortyzacji, ale również z terminową i należytą ściągalnością opłat czynszowych od lokatorów. Oba zjawiska nie tylko mają swoje negatywne odbicie w strukturze kosztów, lecz także wpływają ujemnie na płynność finansową.

Tabela 3. Wskaźniki efektywności DEA spółek komunalnych z branży gospodarki odpadami komunalnymi w latach 2010-2013

\begin{tabular}{|c|c|c|c|c|c|c|}
\hline Miejscowość & Nazwa spółki & 2010 & 2011 & 2012 & 2013 & Średnia \\
\hline 1 & 2 & 3 & 4 & 5 & 6 & 7 \\
\hline $\begin{array}{l}\text { Gmina Miejska } \\
\text { Bolesławiec }\end{array}$ & $\begin{array}{l}\text { Miejski Zakład Gospodarki } \\
\text { Komunalnej Sp. z o.o. w } \\
\text { Bolesławcu }\end{array}$ & 0,105 & 0,105 & 0,102 & 0,098 & 0,103 \\
\hline $\begin{array}{l}\text { Gmina Miejska } \\
\text { Głogów }\end{array}$ & $\begin{array}{l}\text { Głogowskie Przedsiębiorstwo } \\
\text { Komunalne Sita Głogów } \\
\text { Sp. z o.o. }\end{array}$ & 0,070 & 0,070 & 0,075 & 0,071 & 0,072 \\
\hline $\begin{array}{l}\text { Gmina Miejska } \\
\text { Jawor }\end{array}$ & Inwestycje Sp. z o.o. & 0,363 & 0,363 & 1,000 & 0,803 & 0,632 \\
\hline $\begin{array}{l}\text { Gmina Miejska } \\
\text { Jelenia Góra }\end{array}$ & $\begin{array}{l}\text { Miejskie Przedsiębiorstwo } \\
\text { Gospodarki Komunalnej } \\
\text { Sp. z o.o. }\end{array}$ & 0,044 & 0,044 & 0,041 & 0,039 & 0,042 \\
\hline $\begin{array}{l}\text { Gmina Miejska } \\
\text { Legnica }\end{array}$ & $\begin{array}{l}\text { Legnickie Przedsiębiorstwo } \\
\text { Gospodarki Komunalnej } \\
\text { Sp. z o.o. }\end{array}$ & 0,034 & 0,034 & 0,032 & 0,031 & 0,033 \\
\hline $\begin{array}{l}\text { Gmina Miejska } \\
\text { Lubań }\end{array}$ & $\begin{array}{l}\text { Zakład Gospodarki i Usług } \\
\text { Komunalnych Sp. z o.o. }\end{array}$ & 0,134 & 0,134 & 0,115 & 0,074 & 0,114 \\
\hline $\begin{array}{l}\text { Gmina Miejska } \\
\text { Lubin }\end{array}$ & $\begin{array}{l}\text { Mundo Miejskie } \\
\text { Przedsiębiorstwo Gospodarki } \\
\text { Odpadami Sp. z o.o. }\end{array}$ & 0,127 & 0,127 & 0,143 & 0,334 & 0,183 \\
\hline $\begin{array}{l}\text { Gmina Miejska } \\
\text { Lubin }\end{array}$ & $\begin{array}{l}\text { Miejskie Przedsiębiorstwo } \\
\text { Oczyszczania Sp. z o.o. }\end{array}$ & 0,073 & 0,073 & 0,074 & 0,073 & 0,073 \\
\hline $\begin{array}{l}\text { Gmina Miejska } \\
\text { Nowa Ruda }\end{array}$ & $\begin{array}{l}\text { Noworudzkie Usługi Komunalne } \\
\text { Sp. z o.o. }\end{array}$ & 0,203 & 0,203 & 0,204 & 0,167 & 0,194 \\
\hline $\begin{array}{l}\text { Gmina Miejska } \\
\text { Zawidów }\end{array}$ & $\begin{array}{l}\text { Przedsiębiorstwo Usług } \\
\text { Komunalnych Sp. z o.o. }\end{array}$ & 0,625 & 0,625 & 0,624 & 0,632 & 0,627 \\
\hline
\end{tabular}




\begin{tabular}{|c|c|c|c|c|c|c|}
\hline 1 & 2 & 3 & 4 & 5 & 6 & 7 \\
\hline $\begin{array}{l}\text { Gmina Miejska } \\
\text { Zgorzelec }\end{array}$ & $\begin{array}{l}\text { Miejskie Przedsiębiorstwo } \\
\text { Gospodarki Komunalnej } \\
\text { Sp. z o.o. }\end{array}$ & 0,146 & 0,146 & 0,138 & 0,140 & 0,143 \\
\hline $\begin{array}{l}\text { Gmina Miejsko- } \\
\text {-Wiejska } \\
\text { Bogatynia }\end{array}$ & $\begin{array}{l}\text { Gminne Przedsiębiorstwo } \\
\text { Oczyszczania Sp. z o.o. }\end{array}$ & 0,098 & 0,098 & 0,141 & 0,100 & 0,109 \\
\hline $\begin{array}{l}\text { Gmina Miejsko- } \\
\text {-Wiejska } \\
\text { Bystrzyca Kłodzka }\end{array}$ & $\begin{array}{l}\text { Zakład Usług Komunalnych } \\
\text { w Bystrzycy Kłodzkiej Sp. z o.o. }\end{array}$ & 0,349 & 0,349 & 0,231 & 0,273 & 0,301 \\
\hline $\begin{array}{l}\text { Gmina Miejsko- } \\
\text {-Wiejska Wołów }\end{array}$ & $\begin{array}{l}\text { Przedsiębiorstwo Gospodarki } \\
\text { Komunalnej w Wołowie } \\
\text { Sp. z o.o. }\end{array}$ & 0,275 & 0,275 & 0,265 & 0,198 & 0,253 \\
\hline $\begin{array}{l}\text { Gmina Miejsko- } \\
\text {-Wiejska } \\
\text { Ząbkowice Śląskie }\end{array}$ & $\begin{array}{l}\text { Zakład Gospodarki Komunalnej } \\
\text { Sp. z o.o. }\end{array}$ & 0,312 & 0,312 & 0,295 & 0,142 & 0,265 \\
\hline $\begin{array}{l}\text { Gmina Miejsko- } \\
\text {-Wiejska Złoty Stok }\end{array}$ & $\begin{array}{l}\text { Przedsiębiorstwo Produkcyjno- } \\
\text {-Usługowe Koma Sp. z o.o. }\end{array}$ & 1,000 & 1,000 & 1,000 & 1,000 & 1,000 \\
\hline $\begin{array}{l}\text { Gmina Wiejska } \\
\text { Długołęka }\end{array}$ & $\begin{array}{l}\text { Zakład Usług Komunalnych } \\
\text { Sp. z o.o. }\end{array}$ & 0,196 & 0,196 & 0,199 & 0,168 & 0,190 \\
\hline $\begin{array}{l}\text { Gmina Wiejska } \\
\text { Pielgrzymka }\end{array}$ & $\begin{array}{l}\text { Gminne Przedsiębiorstwo } \\
\text { Komunalne Sp. z o.o. }\end{array}$ & 0,368 & 1,000 & 0,524 & 1,000 & 0,723 \\
\hline
\end{tabular}

Źródło: opracowanie własne na podstawie przeprowadzonych badań.

Z zestawionych w tabeli 3 wskaźników efektywności DEA wynika, że tylko jedna spółka $\mathrm{z}$ branży gospodarki odpadami komunalnymi w badanym okresie była efektywna. Pozostałe 17 spółek notowało niższe wskaźniki efektywności, z czego 14 podmiotów poniżej 50\%. Oznacza to, że spółki te były bardzo kosztochłonne i ponosiły nakłady nieadekwatne do określonego poziomu efektów.

Zalecana jest restrukturyzacja kosztowa pozwalającą zminimalizować ponoszone nakłady do dotychczas osiąganych efektów. W szczególności cztery spółki (Miejskie Przedsiębiorstwo Oczyszczania Sp. z o.o. w Lubinie, Głogowskie Przedsiębiorstwo Komunalne Sita Głogów Sp. z o.o., Miejskie Przedsiębiorstwo Gospodarki Komunalnej Sp. z o.o. w Jeleniej Górze, Legnickie Przedsiębiorstwo Gospodarki Komunalnej Sp. z o.o.) powinny aż o około $97 \%$ zminimalizować nakłady w swojej działalności w celu osiągnięcia określonego poziomu efektów.

Wyniki badanych spółek komunalnych świadczących usługi dostarczania wody i odbierania ścieków komunalnych w okresie 2010-2013 pokazują, że zdecydowana większość spółek osiągała niskie wskaźniki efektywności (tab. 4). Tylko sześć spółek wykazało średni wskaźnik ponad 0,500. Oznacza to, że branża wodociągowo-kanalizacyjna jest bardzo kosztochłonna i przeważająca liczba przedsiębiorstw w niej funkcjonujących ponosiła o około 90\% kosztów więcej, niż potrzebne jest do osiągnięcia 
Tabela 4. Wskaźniki efektywności DEA spółek komunalnych z branży wodociągów i kanalizacji w latach 2010-2013

\begin{tabular}{|c|c|c|c|c|c|c|}
\hline Miejscowość & Nazwa spółki & 2010 & 2011 & 2012 & 2013 & Średnia \\
\hline 1 & 2 & 3 & 4 & 5 & 6 & 7 \\
\hline $\begin{array}{l}\text { Gmina Miejska } \\
\text { Dzierżoniów }\end{array}$ & $\begin{array}{l}\text { Wodociągi i Kanalizacja } \\
\text { Sp. z o.o. }\end{array}$ & 0,044 & 0,063 & 0,052 & 0,059 & 0,055 \\
\hline $\begin{array}{l}\text { Gmina Miejska } \\
\text { Góra }\end{array}$ & $\begin{array}{l}\text { Technika Komunalna Tekom } \\
\text { Sp. z o.o. }\end{array}$ & 0,099 & 0,101 & 0,102 & 0,246 & 0,137 \\
\hline $\begin{array}{l}\text { Gmina Miejska } \\
\text { Jelenia Góra }\end{array}$ & $\begin{array}{l}\text { Przedsiębiorstwo Wodociągów } \\
\text { i Kanalizacji Wodnik Sp. z o.o. }\end{array}$ & 0,021 & 0,023 & 0,024 & 0,027 & 0,024 \\
\hline $\begin{array}{l}\text { Gmina Miejska } \\
\text { Kamienna Góra }\end{array}$ & $\begin{array}{l}\text { Miejskie Przedsiębiorstwo } \\
\text { Wodociągów i Kanalizacji } \\
\text { Sp. z o.o. }\end{array}$ & 0,141 & 0,275 & 0,156 & 0,205 & 0,194 \\
\hline $\begin{array}{l}\text { Gmina Miejska } \\
\text { Kłodzko }\end{array}$ & Wodociągi Kłodzkie Sp. z o.o. & 0,115 & 0,096 & 0,102 & 0,120 & 0,108 \\
\hline $\begin{array}{l}\text { Gmina Miejska } \\
\text { Kudowa-Zdrój }\end{array}$ & $\begin{array}{l}\text { Kudowski Zakład Wodociągów } \\
\text { i Kanalizacji Sp. z o.o. }\end{array}$ & 0,153 & 0,155 & 0,118 & 0,143 & 0,142 \\
\hline $\begin{array}{l}\text { Gmina miejska } \\
\text { legnica }\end{array}$ & $\begin{array}{l}\text { Legnickie Przedsiębiorstwo } \\
\text { Wodociągów i Kanalizacji } \\
\text { Sp. z o.o. }\end{array}$ & 0,019 & 0,022 & 0,024 & 0,026 & 0,023 \\
\hline $\begin{array}{l}\text { Gmina Miejska } \\
\text { Lubań }\end{array}$ & $\begin{array}{l}\text { Lubańskie Przedsiębiorstwo } \\
\text { Wodociągów i Kanalizacji } \\
\text { Sp. z o.o. }\end{array}$ & 0,097 & 0,112 & 0,120 & 0,142 & 0,118 \\
\hline $\begin{array}{l}\text { Gmina Miejska } \\
\text { Lubin }\end{array}$ & $\begin{array}{l}\text { Miejskie Przedsiębiorstwo } \\
\text { Wodociągów i Kanalizacji } \\
\text { Sp. z o.o. }\end{array}$ & 0,029 & 0,031 & 0,032 & 0,032 & 0,031 \\
\hline $\begin{array}{l}\text { Gmina Miejska } \\
\text { Oleśnica }\end{array}$ & $\begin{array}{l}\text { Miejska Gospodarka } \\
\text { Komunalna Sp. z o.o. }\end{array}$ & 0,026 & 0,028 & 0,029 & 0,032 & 0,029 \\
\hline $\begin{array}{l}\text { Gmina Miejska } \\
\text { Oława }\end{array}$ & $\begin{array}{l}\text { Zakład Wodociągów } \\
\text { i Kanalizacji Sp. z o.o. } \\
\text { w Oławie }\end{array}$ & 0,084 & 0,088 & 0,094 & 0,109 & 0,094 \\
\hline $\begin{array}{l}\text { Gmina Miejska } \\
\text { Polanica-Zdrój }\end{array}$ & $\begin{array}{l}\text { Miejski Zakład Komunalny } \\
\text { w Polanicy-Zdroju Sp. z o.o. }\end{array}$ & 0,119 & 0,118 & 0,120 & 0,136 & 0,123 \\
\hline $\begin{array}{l}\text { Gmina Miejska } \\
\text { Świdnica }\end{array}$ & $\begin{array}{l}\text { Świdnickie Przedsiębiorstwo } \\
\text { Wodociągów i Kanalizacji } \\
\text { w Świdnicy Sp. z o.o. }\end{array}$ & 0,041 & 0,066 & 0,055 & 0,063 & 0,056 \\
\hline $\begin{array}{l}\text { Gmina Miejska } \\
\text { Świebodzice }\end{array}$ & $\begin{array}{l}\text { Zakład Wodociągów } \\
\text { i Kanalizacji Sp. z o.o. }\end{array}$ & 0,150 & 0,124 & 0,140 & 0,136 & 0,138 \\
\hline $\begin{array}{l}\text { Gmina Miejska } \\
\text { Wrocław }\end{array}$ & $\begin{array}{l}\text { Miejskie Przedsiębiorstwo } \\
\text { Wodociągów i Kanalizacji S.A. }\end{array}$ & 0,004 & 0,008 & 0,002 & 0,004 & 0,005 \\
\hline $\begin{array}{l}\text { Gmina Miejska } \\
\text { Zgorzelec }\end{array}$ & $\begin{array}{l}\text { Przedsiębiorstwo Wodociągów } \\
\text { i Kanalizacji Nysa Sp. z o.o. }\end{array}$ & 0,058 & 0,069 & 0,075 & 0,080 & 0,071 \\
\hline
\end{tabular}




\begin{tabular}{|c|c|c|c|c|c|c|}
\hline 1 & 2 & 3 & 4 & 5 & 6 & 7 \\
\hline $\begin{array}{l}\text { Gmina Miejska } \\
\text { Złotoryja }\end{array}$ & $\begin{array}{l}\text { Rejonowe Przedsiębiorstwo } \\
\text { Komunalne Sp. z o.o. w } \\
\text { Złotoryi }\end{array}$ & 0,065 & 0,079 & 0,084 & 0,094 & 0,081 \\
\hline $\begin{array}{l}\text { Gmina Miejsko- } \\
\text {-Wiejska } \\
\text { Bogatynia }\end{array}$ & $\begin{array}{l}\text { Bogatyńskie Wodociągi } \\
\text { i Oczyszczalnia S.A. }\end{array}$ & 0,039 & 0,029 & 0,027 & 0,034 & 0,032 \\
\hline $\begin{array}{l}\text { Gmina Miejsko- } \\
\text {-Wiejska } \\
\text { Bystrzyca Kłodzka }\end{array}$ & $\begin{array}{l}\text { Zakład Wodociągów } \\
\text { i Kanalizacji Sp. z o.o. } \\
\text { w Bystrzycy Kłodzkiej }\end{array}$ & 0,135 & 0,186 & 0,206 & 0,231 & 0,190 \\
\hline $\begin{array}{l}\text { Gmina Miejsko- } \\
\text {-Wiejska } \\
\text { Chocianów }\end{array}$ & $\begin{array}{l}\text { Przedsiębiorstwo } \\
\text { Wodociągowo- Kanalizacyjne } \\
\text { Sp. z o.o. }\end{array}$ & 1,000 & 0,297 & 0,341 & 1,000 & 0,660 \\
\hline $\begin{array}{l}\text { Gmina Miejsko- } \\
\text {-Wiejska Jelcz- } \\
\text {-Laskowice }\end{array}$ & $\begin{array}{l}\text { Zakład Gospodarki Komunalnej } \\
\text { Sp. z o.o. }\end{array}$ & 0,067 & 0,079 & 0,082 & 0,084 & 0,078 \\
\hline $\begin{array}{l}\text { Gmina Miejsko- } \\
\text {-Wiejska Kąty } \\
\text { Wrocławskie } \\
\end{array}$ & $\begin{array}{l}\text { Zakład Gospodarki Komunalnej } \\
\text { Sp. z o.o. }\end{array}$ & 0,102 & 0,162 & 0,117 & 0,101 & 0,121 \\
\hline $\begin{array}{l}\text { Gmina Miejsko- } \\
\text {-Wiejska } \\
\text { Nowogrodziec }\end{array}$ & Hydro Tech Sp. z o.o. & 0,177 & 0,188 & 0,188 & 0,206 & 0,190 \\
\hline $\begin{array}{l}\text { Gmina Miejsko- } \\
\text {-Wiejska Oborniki } \\
\text { Śląskie }\end{array}$ & $\begin{array}{l}\text { Zakład Gospodarki Komunalnej } \\
\text { Sp. z o.o. }\end{array}$ & 0,104 & 1,000 & 0,121 & 0,139 & 0,341 \\
\hline $\begin{array}{l}\text { Gmina Miejsko- } \\
\text {-Wiejska } \\
\text { Polkowice }\end{array}$ & $\begin{array}{l}\text { Przedsiębiorstwo Gospodarki } \\
\text { Miejskiej Sp. z o.o. }\end{array}$ & 0,022 & 0,026 & 0,028 & 0,029 & 0,026 \\
\hline $\begin{array}{l}\text { Gmina Miejsko- } \\
\text {-Wiejska Strzegom }\end{array}$ & $\begin{array}{l}\text { Wodociągi i Kanalizacja } \\
\text { Sp. z o.o. }\end{array}$ & 0,096 & 0,112 & 0,116 & 0,102 & 0,107 \\
\hline $\begin{array}{l}\text { Gmina Miejsko- } \\
\text {-Wiejska Strzelin }\end{array}$ & $\begin{array}{l}\text { Zakład Wodociągów } \\
\text { i Kanalizacji Sp. z o.o. }\end{array}$ & 0,049 & 0,025 & 0,026 & 0,074 & 0,044 \\
\hline $\begin{array}{l}\text { Gmina Miejsko- } \\
\text {-Wiejska Syców }\end{array}$ & $\begin{array}{l}\text { Sycowska Gospodarka } \\
\text { Komunalna Sp. z o.o. }\end{array}$ & 0,112 & 0,166 & 0,128 & 0,144 & 0,138 \\
\hline $\begin{array}{l}\text { Gmina Miejsko- } \\
\text {-Wiejska Środa } \\
\text { Śląska }\end{array}$ & Średzka Woda Sp. z o.o. & 0,148 & 0,154 & 0,136 & 0,173 & 0,153 \\
\hline $\begin{array}{l}\text { Gmina Miejsko- } \\
\text {-Wiejska Wołów }\end{array}$ & $\begin{array}{l}\text { Przedsiębiorstwo Wodno- } \\
\text {-Kanalizacyjne Wołów Sp. z o.o. }\end{array}$ & 0,136 & 0,136 & 0,129 & 0,260 & 0,165 \\
\hline $\begin{array}{l}\text { Gmina Miejsko- } \\
\text {-Wiejska } \\
\text { Ząbkowice } \\
\text { Śląskie }\end{array}$ & $\begin{array}{l}\text { Przedsiębiorstwo Wodociągów } \\
\text { i Kanalizacji Delfin Sp. z o.o. }\end{array}$ & 0,125 & 0,139 & 0,149 & 0,163 & 0,144 \\
\hline
\end{tabular}


Tabela 4, cd.

\begin{tabular}{|l|l|c|c|c|c|c|}
\hline \multicolumn{1}{|c|}{1} & \multicolumn{1}{|c|}{2} & \multicolumn{1}{c|}{4} & \multicolumn{1}{c|}{5} & 6 & 7 \\
\hline $\begin{array}{l}\text { Gmina Miejsko- } \\
\text {-Wiejska Ziębice }\end{array}$ & $\begin{array}{l}\text { Zakład Wodociągów } \\
\text { i Kanalizacji w Ziębicach } \\
\text { Sp. z o.o. }\end{array}$ & 0,180 & 0,173 & 0,195 & 0,193 & 0,185 \\
\hline $\begin{array}{l}\text { Gmina Miejsko- } \\
\text {-Wiejska Złoty Stok }\end{array}$ & $\begin{array}{l}\text { Przedsiębiorstwo Produkcyjno- } \\
\text {-Usługowe Wod.-Kan. Sp. z o.o. }\end{array}$ & 1,000 & 1,000 & 1,000 & 1,000 & 1,000 \\
\hline $\begin{array}{l}\text { Gmina Miejsko- } \\
\text {-Wiejska Żarów }\end{array}$ & $\begin{array}{l}\text { Przedsiębiorstwo Wodno- } \\
\text {-Ściekowe Sp. z o.o. }\end{array}$ & 0,591 & 0,453 & 0,513 & 0,553 & 0,528 \\
\hline $\begin{array}{l}\text { Gmina Miejsko- } \\
\text {-Wiejska Żarów }\end{array}$ & $\begin{array}{l}\text { Zakład Wodociągów } \\
\text { i Kanalizacji w Żarowie } \\
\text { Sp. z o.o. }\end{array}$ & 0,281 & 0,290 & 0,313 & 0,332 & 0,304 \\
\hline $\begin{array}{l}\text { Gmina Wiejska } \\
\text { Dobroszyce }\end{array}$ & $\begin{array}{l}\text { Gminna Gospodarka } \\
\text { Komunalna Dobroszyce } \\
\text { Sp. z o.o. }\end{array}$ & 0,321 & 0,331 & 0,396 & 0,426 & 0,369 \\
\hline $\begin{array}{l}\text { Gmina Wiejska } \\
\text { Malczyce }\end{array}$ & $\begin{array}{l}\text { Malczyckie Usługi Komunalne } \\
\text { Sp. z o.o. }\end{array}$ & 1,000 & 0,539 & 0,717 & 0,692 & 0,737 \\
\hline $\begin{array}{l}\text { Gmina Wiejska } \\
\text { Miękinia }\end{array}$ & $\begin{array}{l}\text { Zakład Usług Komunalnych } \\
\text { Sp. z o.o. }\end{array}$ & 0,195 & 0,191 & 0,207 & 0,203 & 0,199 \\
\hline $\begin{array}{l}\text { Gmina Wiejska } \\
\text { Oleśnica }\end{array}$ & $\begin{array}{l}\text { Gminne Przedsiębiorstwo } \\
\text { Komunalne Sp. z o.o. }\end{array}$ & 0,414 & 1,000 & 0,418 & 0,448 & 0,570 \\
\hline $\begin{array}{l}\text { Gmina Wiejska } \\
\text { Stoszowice }\end{array}$ & $\begin{array}{l}\text { Wodociągi Srebrnogórskie } \\
\text { Sp. z o.o. }\end{array}$ & 1,000 & 0,764 & 0,924 & 0,683 & 0,843 \\
\hline $\begin{array}{l}\text { Gmina Wiejska } \\
\text { Świdnica }\end{array}$ & $\begin{array}{l}\text { Świdnickie Gminne } \\
\text { Przedsiębiorstwo Komunalne } \\
\text { Sp. z o.o. }\end{array}$ & 0,429 & 1,000 & 1,000 & 0,333 & 0,691 \\
\hline
\end{tabular}

Źródło: opracowanie własne na podstawie przeprowadzonych badań.

określonego poziomu efektów. Wynikać to może z charakteru samej infrastruktury komunalnej wykorzystywanej do świadczenia usług wodociągowo-kanalizacyjnych, a więc z wysokiej amortyzacji oraz awaryjności. Ponadto warto również zauważyć, że na przestrzeni badanych lat wskaźnik efektywności nie odbiegał znacząco od średniej.

\section{Zakończenie}

W sektorze publicznym znaczącą rolę pełnią spółki prawa handlowego, których podstawowym celem działalności jest dostarczanie usług użyteczności publicznej. Są one wyposażone w kapitał jednostek samorządu terytorialnego, który efektywnie zarządzany powinien podnosić jakość świadczonych usług publicznych i tym samym właściwie zaspokajać potrzeby publiczne.

Za pomocą nieparametrycznej metody DEA dokonano pomiaru efektywności wybranych spółek komunalnych z województwa dolnośląskiego, których główny 
przedmiot działalności dotyczył świadczenia usług z zakresu gospodarki mieszkaniowej, odpadów komunalnych oraz wodociągów i kanalizacji.

Zaprezentowane wyniki dowiodły niskiej efektywności działania zorientowanej na minimalizację kosztów przy dotychczas osiąganym poziomie efektów. Podkreśliły różnice pomiędzy kondycją ekonomiczno-finansową spółek ze względu na rodzaj prowadzonej działalności. Część branż, z racji specyfiki świadczonych usług i zaspokajanych potrzeb mieszkańców, jest wysoko kapitałochłonna i nierentowna. Inne z kolei rentowne i przynoszące dochody jednostkom samorządu terytorialnego $\mathrm{z}$ wniesionych nakładów.

Badania wykazały, że lepsze wskaźniki efektywności uzyskiwały spółki z branży gospodarki mieszkaniowej. $Z$ kolei podmioty świadczące usługi w ramach branży wodociągów i kanalizacji oraz gospodarki odpadami komunalnymi wykazywały niską efektywność działalności.

Pomimo że nieparametryczna metoda DEA zawiera kilka uproszczeń, to przede wszystkim może stanowić praktyczny instrument pomiaru efektywności działania spółek z kapitałem publicznym. Ponadto umożliwia zobrazowanie ogólnego poziomu produktywności badanych podmiotów w ujęciu branżowym oraz przeanalizowanie procesu kształtowania się w poszczególnych latach. Należy podkreślić, że otrzymane wskaźniki efektywności obrazują spółki efektywnie gospodarujące posiadanymi zasobami, a także wskazują na potencjalną skalę usprawnień spółkom nieefektywnym, które prowadząc tę samą działalność, ponoszą znacznie większe nakłady, niż wynika to z poziomu efektów. Dodatkowo metoda pozwala na przeprowadzenie symulacji polegającej na doborze innych nakładów i efektów do modelu, w zależności od specyfiki analizowanych spółek.

Podsumowując, efektywne spółki komunalne mogą być wzorem do projektowania i realizowania procesów produkcyjnych przez inne podmioty z sektora komunalnego. Ponadto nieparametryczna metoda DEA powinna stanowić dopełnienie kompleksowej i wnikliwej oceny efektywności spółek jednostek samorządu terytorialnego przez właścicieli oraz kadrę nadzorczą i zarządzającą.

\section{Literatura}

Bachor W., 2009, Efektywność majątku trwałego w spótkach komunalnych, Szkoła Główna Handlowa, Warszawa.

Borkowski B., Dudek H., Szczęsny W., 2003, Ekonometria, wybrane zagadnienia, PWN, Warszawa.

Cameron K.S., Whetten D.A., 1983, Organizational Effectiveness: A comparison of multiple models, Academic Press, New York.

Ćwiąkała-Małys A., Nowak W., 2009, Sposoby klasyfikacji modeli DEA, Badania Operacyjne i Decyzje, nr 3, s. 5-18.

Gajdzik B., 2015, Próba implementacji metody DEA do oceny efektywności procesu restrukturyzacji sektora hutniczego w Polsce, [w:] Innowacje w zarzadzaniu i inżynierii produkcji, red. R. Knosala, Polskie Towarzystwo Zarządzania Produkcją, Opole. 
Gruszewski T., 2002, Wspótczesne teorie przedsiębiorstwa, PWN, Warszawa.

Grzymała Z., 2010, Formy organizacyjno-prawne przedsiębiorstw komunalnych i ich wplyw na efektywność, Szkoła Główna Handlowa, Warszawa.

Guzik B., 2009, Podstawowe modele DEA w badaniu efektywności gospodarczej i społecznej, Uniwersytet Ekonomiczny w Poznaniu, Poznań.

Jurek A., 2005, Porównanie parametrycznych i nieparametrycznych metod estymacji w ocenie efektywności wybranych spótek hodowlanych Agencji Nieruchomości Rolnych, Roczniki Naukowe Stowarzyszenia Ekonomistów Rolnictwa i Agrobiznesu, nr 7, s. 121-127.

Kachniarz M., 2002, Efektywność ustug publicznych - teoria i praktyka, Akademia Ekonomiczna we Wrocławiu, Wrocław.

Kozłowska J., 2014, Zastosowanie metody DEA w analizie efektywności działania przedsiębiorstw uslugowych, Zeszyty Naukowe Politechniki Śląskiej, Seria: Organizacja i Zarządzanie, nr 73, s. 305-317.

Leszczyński Z., Skowronek-Mielczarek A., 2004, Analiza ekonomiczno-finansowa spótki, PWE, Warszawa.

Malinowski P., 2013, Spótki prawa handlowego w działalności gospodarczej samorzadu powiatowego, Difin, Warszawa.

Pawłowska M., 2005, Konkurencja i efektywność na polskim rynku bankowym na tle zmian strukturalnych i technologicznych, Materiały i Studia NBP, nr 192.

Rogowski W., Pawłowska M., Kopczewski T., 2003, Podstawowe formy i efekty władania korporacyjnego (corporate governance) w bankowości, część II, Bank i Kredyt, nr 4, s. 49-59.

Rybicki W., 2005, O wielostronności, relatywizmie i złożoności kategorii efektywności, [w:] Efektywność - rozważania nad istota i pomiarem, red. T. Dudycz, Akademia Ekonomiczna we Wrocławiu, Wrocław.

Samuelson P.A., Nordhaus W.D., 1999, Ekonomia, PWN, Warszawa.

Savas E.S., 1992, Prywatyzacja. Klucz do lepszego rzadzenia, PWN, Warszawa.

Szymańska E., 2010, Efektywność przedsiębiorstw - definiowanie i pomiar, Roczniki Nauk Rolniczych, Seria G, nr 97, s. 152-164.

Wojciechowski E., 2003, Zarządzanie w samorządzie terytorialnym, Difin, Warszawa.

Wrzosek S., 1994, Ocena efektywności rzeczowych inwestycji przedsiębiorstw, SIGMA, Wrocław. 